\title{
Plasma active vitamin D concentration in low birthweight infants with rickets and its response to vitamin $\mathrm{D}$ treatment
}

\author{
YOSHIKI SEINO, TSUNEYASU ISHII, TSUNESUKE SHIMOTSUJ, MAKOTO ISHIDA, \\ AND HYAKUJI YABUUCHI
}

Department of Paediatrics, Osaka University Hospital, Japan

SUMMARY Impairment of 25-hydroxylation may be a cause of rickets in infants of low birthweight, weighing between 2000 and $2500 \mathrm{~g}$. In addition there may be impairment of $1 \alpha$-hydroxylation in infants weighing less than $2000 \mathrm{~g}$. Our data show that a supplementary dose of vitamin D2 of at least $500 \mathrm{IU}$ daily is a reasonable regimen for infants who weighed between 2000 and $2500 \mathrm{~g}$ at birth. However for infants who weighed less than $2000 \mathrm{~g}$ with a gestation of under 38 weeks, administration of $1 \alpha-\mathrm{OHD}_{3}$ may be more effective in preventing rickets.

Infantile rickets is often found in low birthweight infants ${ }^{1}$ and low concentrations of plasma 25hydroxyvitamin D (25-OHD) have been reported ${ }^{2}$. Lack of vitamin $\mathbf{D}$ due to a decreased supply of nutrients transported across the placenta ${ }^{34}$ and to poor intestinal absorption ${ }^{56}$ are contributory factors. Such infants moreover, have a greater requirement for vitamin $D$ because of more rapid bone growth. ${ }^{78}$ Furthermore, it is likely that impairment of 25-hydroxylation in the liver ${ }^{6} 9$ and of $1 \alpha$-hydroxylation in the kidney contribute to the presence of rickets in infants of low birthweight. In this study of the pathogenesis of rickets in low birthweight infants we consider whether the administration of vitamin D2 or its analogue $1 \alpha-\mathrm{OHD}_{3}$ can prevent rickets.

\section{Materials and methods}

A study was made of 147 infants of low birthweight $(<2500 \mathrm{~g}$ at birth), whose gestation was between 25 and 42 weeks, and for whom parental permission for the study was obtained. All infants were fed a formula comprising the following: calcium $14 \cdot 35$ $\mathrm{mmol} / \mathrm{l}$, phosphorus $12.09 \mathrm{mmol} / \mathrm{l}$, and vitamin D2 $560 \mathrm{IU} / \mathrm{l}$. Each infant was placed in one of three groups: group A infants received no daily supplement of vitamin D apart from that supplied by the formula. Group B infants received $500 \mathrm{IU}$ a day of vitamin D2 in addition to that supplied by the formula, starting after the first week of life. Group C infants received $0 \cdot 1-0 \cdot 15 \mu \mathrm{g} / \mathrm{kg}$ a day of $1 \alpha-\mathrm{OHD}_{3}$ in addition to the basic formula, starting after the first week of life. The diagnosis of rickets was made radiographically between ages 3 and 5 months, usıng the following standard criteria: $:^{10}$

(1) Roentgenographical evidence of enlargement, cupping, and fraying of epiphyseal line.

(2) Rarefaction and irregular fraying of the zone of provisional calcification of the radius or ulna, with some splaying of the metaphyses.

Samples of blood were taken after a 3-hour fast during autumn, winter, and spring. None of the mothers had hypocalcaemia, hypophosphataemia, or bone disease. Plasma $25-\mathrm{OHD}^{11}$ and 1,25dihydroxyvitamin $\mathrm{D}\left(1,25(\mathrm{OH})_{2} \mathrm{D}\right)^{12}$ were measured by using competitive protein binding assay. Plasma $(3 \mathrm{ml})$ was assayed for $1,25(\mathrm{OH})_{2} \mathrm{D}$ by competitive protein binding assay and intestinal cytosol preparations from rachitic chicks were used as the binding protein. The method involves extraction with dichloromethane chromatography on separated LH-20 (Pharmacia Fine Chemical Company) followed by separation on silicic acid columns with the use of high pressure liquid chromatography (Waters Associates, Milford, Mass). The assays were performed with a known internal standard to determine recovery from the plasma samples. The standard curve incubations were carried out in quadruplicate and the sample incubations were performed in triplicate. With this method the mean concentration for the 9 term infants (1 week-6 months) was $72 \cdot 0 \pm 27 \cdot 3$ (mean \pm SD) ${ }^{12} \mathrm{pg} / \mathrm{ml}$. Serum calcium, phosphorus, and 
alkaline phosphate were measured with an autoanalyser.

\section{Results}

Vitamin D intake in each group was measured. The infants in group A had received 50-400 IUf of vitamin D2 a day until aged 3 months and then they received 400-650 IU a day. The vitamin D2 intake in group B had averaged 50 IU a day until the end of the second week of life, and then was 550-1150 IU a day. The $1 \alpha-\mathrm{OHD}_{3}$ intake in group $\mathrm{C}$ had been $0 \cdot 1-0 \cdot 3 \mu \mathrm{g}$ a day since the second week of life, in addition to an average of 470 IU vitamin D2 a day.
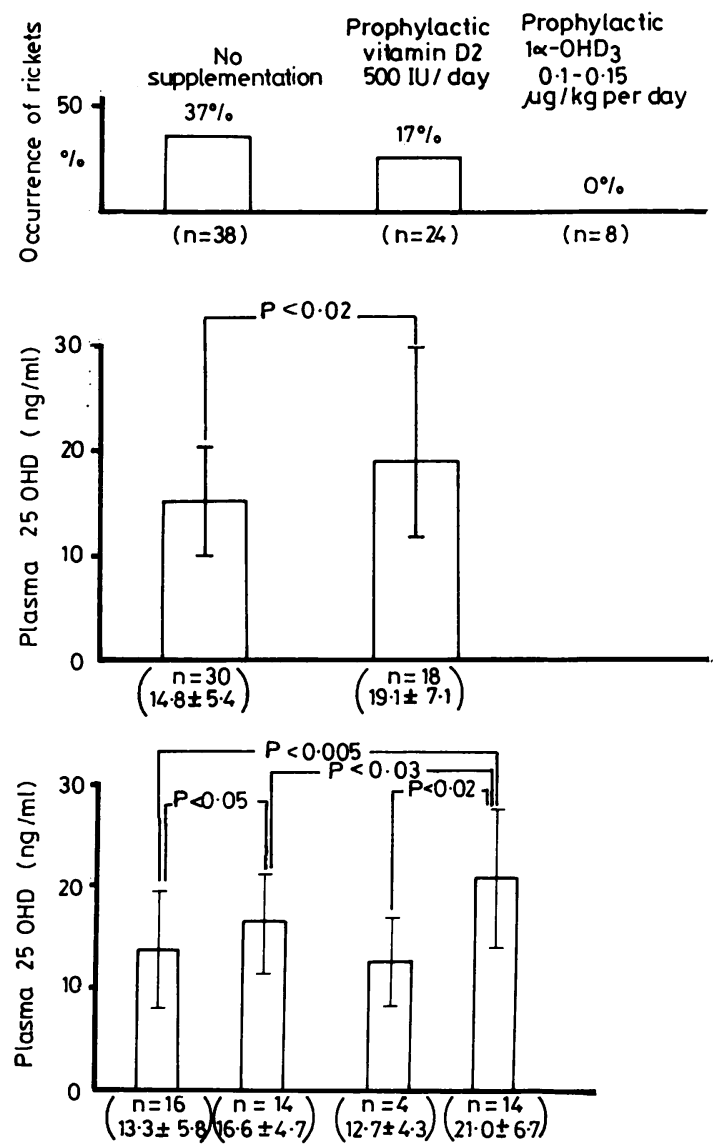

Rickets $\quad(+) \quad(-) \quad(+) \quad(-)$

Fig. 1 Plasma 25-OHD concentrations (mean $\pm S D$ ) at 3-5 months and the incidence of rickets in infants weighing 2000-2500 $\mathrm{g}$ at birth.
Plasma 25-OHD concentrations at 3-5 months and the incidence of rickets in infants weighing $2000-2500 \mathrm{~g}$ at birth are shown in Fig. 1.

Rickets occurred in $14(37 \%)$ of the 38 infants in group A and in 4 (17\%) of the 24 infants in group B; no rickets was present in group $C$. The mean plasma 25-OHD concentration in group B infants was significantly greater than that in group $\mathbf{A}$ infants, the mean plasma 25-OHD concentration in group $\mathrm{A}$ infants without rickets was significantly greater than that in group $A$ infants with rickets, and the mean plasma 25-OHD concentration in group B infants without rickets was significantly greater than that in infants with rickets, and markedly greater than that in group $\mathrm{A}$ infants with rickets.

Plasma 25-OHD concentrations at 3-5 months
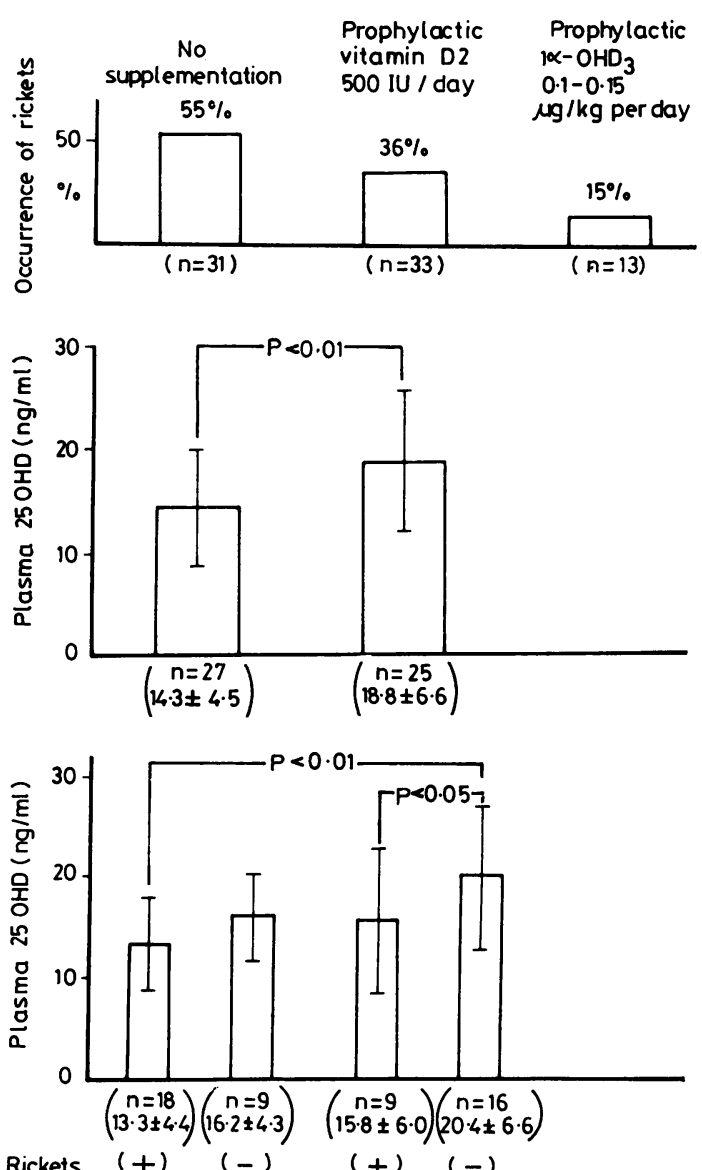

Fig. 2 Plasma 25-OHD concentrations (mean $\pm S D$ ) at 3-5 months and the incidence of rickets in infants weighing less than $2000 \mathrm{~g}$ at birth. 

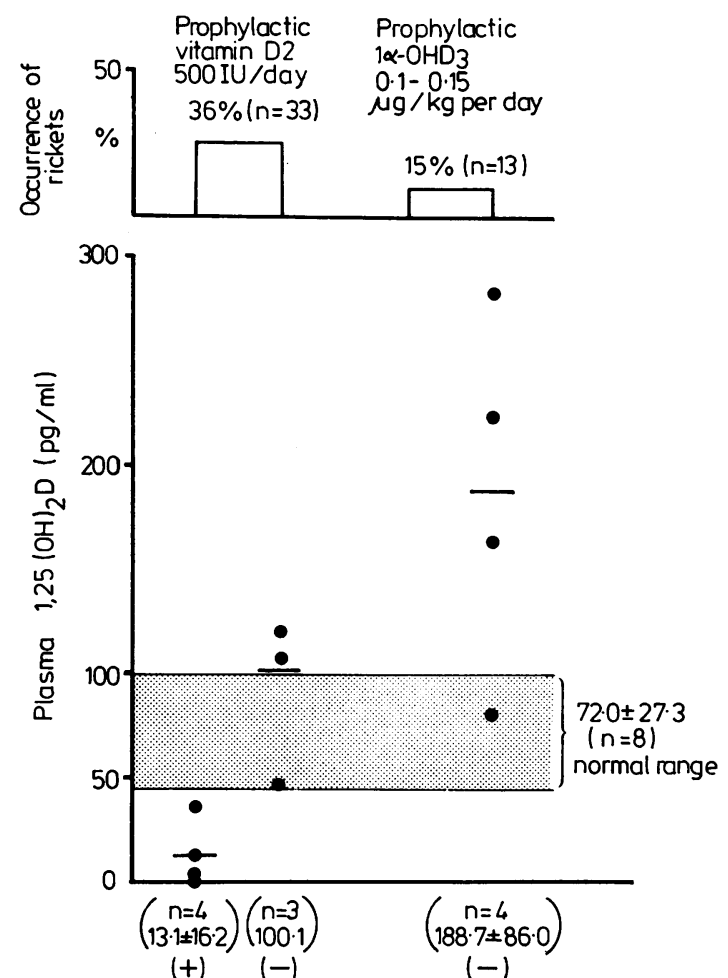

Fig. 3 Plasma 1,25 $(\mathrm{OH})_{2} \mathrm{D}$ concentrations (mean $\pm \mathrm{SD}$ ) and the incidence of rickets in infants weighing less than $2000 \mathrm{~g}$ at birth. and the incidence of rickets in infants weighing less than $2000 \mathrm{~g}$ at birth are shown in Fig. 2.

Rickets occurred in $17(55 \%)$ of the 31 infants in group A and in $12(36 \%)$ of the 33 infants in group B, but it was present in only 2 of the 13 infants in

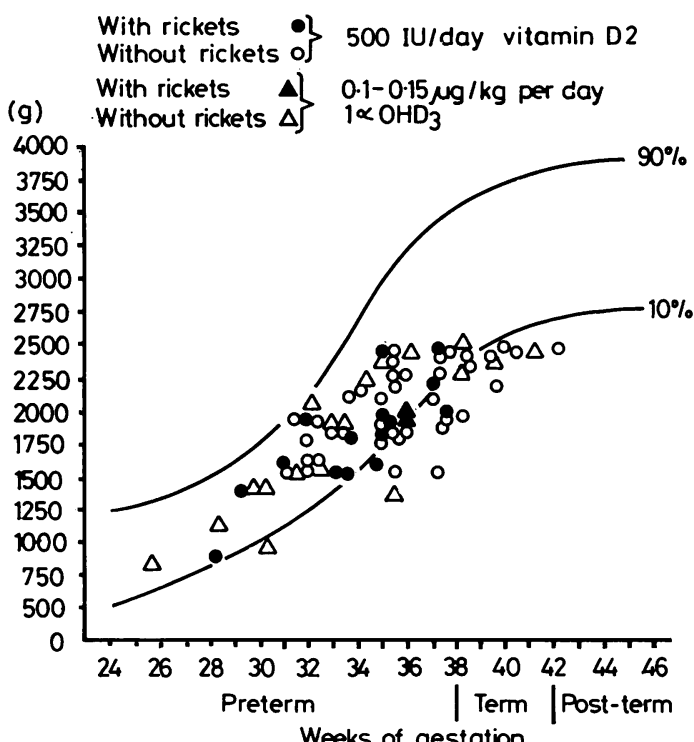

Fig. 4 Birthweight and gestational age of infants ${ }^{17}$ treated prophylactically with vitamin $\mathrm{D} 2$ and $1 \alpha-O H D_{3}$ (normal range; Seino et al. ${ }^{12}$ ).

Table 1 Serum calcium, phosphorus, and alkaline phosphatase levels (mean $\pm S D$ ) in infants weighing 2000-2500 g at birth

\begin{tabular}{|c|c|c|c|c|c|c|c|c|c|}
\hline \multirow[t]{2}{*}{ Rickets } & \multicolumn{3}{|c|}{ No supplements } & \multicolumn{3}{|c|}{ Vitamin D2 (500 IU/day) } & \multicolumn{3}{|c|}{$1 \alpha-O H D_{3}(0.1-0.15 \mu g / k g$ a day $)$} \\
\hline & $\begin{array}{l}\text { Calcium } \\
(\mathrm{mmol} / \mathrm{l})\end{array}$ & $\begin{array}{l}\text { Phosphorus } \\
\text { (mmol/l) }\end{array}$ & $\begin{array}{l}\text { Alkaline } \\
\text { phosphatase } \\
\text { (KA units) }\end{array}$ & $\begin{array}{l}\text { Calcium } \\
(\mathrm{mmol} / \mathrm{l})\end{array}$ & $\begin{array}{l}\text { Phosphorus } \\
\text { (mmol/l) }\end{array}$ & $\begin{array}{l}\text { Alkaline } \\
\text { phosphatase } \\
\text { (KA units) }\end{array}$ & $\begin{array}{l}\text { Calcium } \\
(\mathrm{mmol} / \mathrm{l})\end{array}$ & $\begin{array}{l}\text { Phosphorus } \\
\text { (mmol/l) }\end{array}$ & $\begin{array}{l}\text { Alkaline } \\
\text { phosphatase } \\
\text { (KA units) }\end{array}$ \\
\hline $\begin{array}{l}\text { Absent } \\
\text { Present } \\
\text { Normal range }\end{array}$ & $\begin{array}{l}2 \cdot 45 \pm 0 \cdot 25 \\
(n=14) \\
2 \cdot 35 \pm 0 \cdot 15 \\
(n=16) \\
2 \cdot 25-2 \cdot 75\end{array}$ & $\begin{array}{l}2 \cdot 21 \pm 0 \cdot 29 \\
(n=14) \\
1 \cdot 98 \pm 0 \cdot 32 \\
(n=16) \\
1 \cdot 44-2 \cdot 20\end{array}$ & $\begin{array}{l}23 \cdot 6 \pm 8 \cdot 4 \\
(n=14) \\
33 \cdot 7 \pm 0 \cdot 6 \\
(n=16) \\
18 \cdot 8-36 \cdot 0\end{array}$ & $\begin{array}{l}2 \cdot 55 \pm 0 \cdot 15 \\
(n=14) \\
2 \cdot 55 \pm 0 \cdot 2 \\
(n=4)\end{array}$ & $\begin{array}{l}1 \cdot 98 \pm 0 \cdot 29 \\
(n=14) \\
1 \cdot 98 \pm 0 \cdot 32 \\
(n=4)\end{array}$ & $\begin{array}{l}30 \cdot 8 \pm 11 \cdot 1 \\
(n=14) \\
31 \cdot 1 \pm 3 \cdot 6 \\
(n=4)\end{array}$ & $\begin{array}{l}2 \cdot 60 \pm 0 \cdot 10 \\
(n=10) \\
-\end{array}$ & $\begin{array}{l}2 \cdot 02 \pm 0 \cdot 26 \\
(n=10) \\
-\end{array}$ & $\begin{array}{l}32 \cdot 6 \pm 21 \cdot 5 \\
(n=10) \\
-\end{array}$ \\
\hline
\end{tabular}

Table 2 Serum calcium, phosphorus, and alkaline phosphatase levels (mean $\pm S D$ ) in infants weighing less than $2000 \mathrm{~g}$ at birth

\begin{tabular}{|c|c|c|c|c|c|c|c|c|c|}
\hline \multirow{2}{*}{ Rickets } & \multicolumn{3}{|c|}{ No supplements } & \multicolumn{3}{|c|}{ Vitamin D2 (500 IU/day) } & \multicolumn{3}{|c|}{$1 \alpha-O H D_{3}(0 \cdot 1-0.15 \mu g / k g$ a day $)$} \\
\hline & $\begin{array}{l}\text { Calcium } \\
(\mathrm{mmol} / \mathrm{l})\end{array}$ & $\begin{array}{l}\text { Phosphorus } \\
\text { (mmol/l) }\end{array}$ & $\begin{array}{l}\text { Alkaline } \\
\text { phosphatase } \\
\text { (KA units) }\end{array}$ & $\begin{array}{l}\text { Calcium } \\
(\mathrm{mmol} / \mathrm{l})\end{array}$ & $\begin{array}{l}\text { Phosphorus } \\
\text { (mmol/l) }\end{array}$ & $\begin{array}{l}\text { Alkaline } \\
\text { phosphatase } \\
\text { (KA units) }\end{array}$ & $\begin{array}{l}\text { Calcium } \\
(\mathrm{mmol} / \mathrm{l})\end{array}$ & $\begin{array}{l}\text { Phosphorus } \\
\text { ( } \mathrm{mmol} / \mathrm{l} \text { ) }\end{array}$ & $\begin{array}{l}\text { Alkaline } \\
\text { phosphatase } \\
\text { (KA units) }\end{array}$ \\
\hline $\begin{array}{l}\text { Absent } \\
\text { Present }\end{array}$ & $\begin{array}{l}2 \cdot 43 \pm 0 \cdot 25 \\
(n=9) \\
2 \cdot 38 \pm 0 \cdot 25 \\
(n=18)\end{array}$ & $\begin{array}{l}2 \cdot 11 \pm 0 \cdot 32 \\
(n=9) \\
1 \cdot 95 \pm 0.42 \\
(n=18)\end{array}$ & $\begin{array}{l}31 \cdot 0 \pm 11 \cdot 0 \\
(n=9) \\
44 \cdot 3 \pm 17 \cdot 6 \\
(n=18)\end{array}$ & $\begin{array}{l}2 \cdot 50 \pm 0 \cdot 15 \\
(n=16) \\
2 \cdot 48 \pm 0 \cdot 10 \\
(n=9)\end{array}$ & $\begin{array}{l}2 \cdot 08 \pm 0 \cdot 19 \\
(n=16) \\
1 \cdot 89 \pm 0 \cdot 13 \\
(n=9)\end{array}$ & $\begin{array}{l}31 \cdot 2 \pm 11 \cdot 5 \\
(n=16) \\
40 \cdot 7 \pm 19 \cdot 6 \\
(n=9)\end{array}$ & $\begin{array}{l}2 \cdot 55 \pm 0 \cdot 20 \\
(n=8) \\
2 \cdot 55 \\
2 \cdot 50(n=3) \\
2 \cdot 05\end{array}$ & $\begin{array}{l}1 \cdot 89 \pm 0 \cdot 22 \\
(n=8) \\
1 \cdot 86 \\
1 \cdot 73(n=3) \\
1 \cdot 57\end{array}$ & $\begin{array}{l}30 \cdot 2 \pm 19 \cdot 0 \\
(n=8) \\
30 \cdot 2 \\
31 \cdot 9(n=3) \\
31 \cdot 0\end{array}$ \\
\hline
\end{tabular}


group C. Although the mean plasma 25-OHD concentration in group B infants was significantly greater than that in group $A$ infants and the mean plasma 25-OHD concentration in group B infants without rickets was significantly greater than that in group A and group B infants with rickets, the mean plasma 25-OHD concentration in group $\mathbf{A}$ and group B infants with rickets was not significantly lower than that in group A infants without rickets.

Plasma $1,25(\mathrm{OH})_{2} \mathrm{D}$ concentrations and the incidence of rickets in infants weighing less than $2000 \mathrm{~g}$ at birth are shown in Fig. 3.

The plasma $1,25(\mathrm{OH})_{2} \mathrm{D}$ concentrations in group $B$ infants with rickets were significantly lower than those in group $B$ infants without rickets $(P<0 \cdot 01)$. Although there was a wide variation, the mean plasma $1,25(\mathrm{OH})_{2} \mathrm{D}$ concentration in group $\mathrm{C}$ infants was higher than that in the controls of term infants.

There was not a significant rise of serum calcium in group $\mathrm{C}$ infants (Tables 1 and 2).

Birthweights and gestational ages of infants treated prophylactically with vitamin D2 and $1 \alpha-\mathrm{OHD}_{3}$ are shown in Fig. 4. It seems that in preterm infants in whom gestation was less than 38 weeks, $1 \alpha-\mathrm{OHD}_{3}$ prevented rickets better than vitamin D2.

\section{Discussion}

It has been suggested that the hydroxylation of vitamin D to $25-\mathrm{OHD}$, and 25-OHD to $1,25(\mathrm{OH})_{2} \mathrm{D}$ may be impaired in extremely low birthweight infants. ${ }^{9}$ The present study does not prove conclusively that impairment of 25 -hydroxylation or poor intestinal absorption of vitamin $D$ exists in infants weighing $2000-2500 \mathrm{~g}$ at birth since the administration of vitamin D2 (500 IU/day) significantly increased plasma 25-OHD concentration. However, an oral supplement of 500 IU a day of vitamin D2 did not change the plasma 25-OHD concentration in the infants with rickets. From these results we cannot be sure which is the main cause of rickets-poor intestinal absorption or impairment of 25-hydroxylation-since we did not give intravenous vitamin $D$ supplements to the infants. Hillman et al. showed that neither oral nor intravenous vitamin $\mathbf{D}$ supplementation increased serum 25-OHD levels in preterm infants, ${ }^{9}$ so we think that a block in hepatic 25-hydroxylation is the more likely alternative. The maternal supply of vitamin D would not seem to be unusual for our subjects; no mother had hypocalcaemia, hypophosphataemia, or bone disease. Nevertheless, in our infants weighing 2000-2500 g at birth the impairment of 25-hydroxylation might have caused rickets.
Although in infants weighing less than $2000 \mathrm{~g}$ at birth the administration of 500 IU a day of vitamin D2 significantly increased the plasma 25-OHD concentration, the incidence of rickets in this group was still high ( $36 \%)$. There seems to be an impairment of 25-hydroxylation in these infants, since plasma 25-OHD concentrations were not changed by the administration of vitamin D2. At the same time, higher requirement for vitamin $D$ seems to be causing rickets ${ }^{8}$ in infants weighing less than $2000 \mathrm{~g}$ at birth because the mean plasma 25-OHDconcentration in group A and group B infants with rickets was not appreciably lower than that in group $A$ infants without rickets. There may be an impairment of $1 \alpha$-hydroxylation in the rickets of infants weighing less than $2000 \mathrm{~g}$ at birth, since plasma $1,25(\mathrm{OH})_{2} \mathrm{D}$ concentrations were low. It is possible that the conversion of $25-\mathrm{OHD}$ to $1,25(\mathrm{OH})_{2} \mathrm{D}$ is more depressed in infants weighing less than $2000 \mathrm{~g}$ than in infants weighing between 2000 and $2500 \mathrm{~g}$.

$1 \alpha-\mathrm{OHD}_{3}$, which is rapidly converted to $1,25(\mathrm{OH})_{2} \mathrm{D}_{3},{ }^{13}$ has been considered a valuable substitute for $1,25(\mathrm{OH})_{2} \mathrm{D} \cdot{ }^{14} \mathrm{~A}$ physiological dose of $1 \alpha-\mathrm{OHD}_{3}$ is considered to be $0.04-0.08 \mu \mathrm{g} / \mathrm{kg}$ a day in children. ${ }^{15}$ In vitamin $D$ dependency, which is believed to be the result of deficient $1 \alpha$-hydroxylation of $25-\mathrm{OHD}$, treatment with $1 \alpha-\mathrm{OHD}_{3}$ by mouth in small doses, considered to be in the physiological range $(0 \cdot 08-0 \cdot 1 \mu \mathrm{g} / \mathrm{kg}$ a day), corrected the biochemical and clinical symptoms. ${ }^{16}$ In the present study fairly high doses of $1 \alpha-\mathrm{OHD}_{3}(0 \cdot 1-0 \cdot 15$ $\mu \mathrm{g} / \mathrm{kg}$ a day) decreased the incidence of rickets in infants weighing less than $2000 \mathrm{~g}$ at birth, and increased the plasma $1,25(\mathrm{OH})_{2} \mathrm{D}$ concentrations. These results support our assumption that an impairment of $1 \alpha$-hydroxylation as well as of 25-hydroxylation may exist in infants weighing less than $2000 \mathrm{~g}$ at birth.

The results of the study suggest that low birthweight infants receiving formula feeds should be maintained on a supplemental vitamin D intake. From these data a supplemental vitamin D2 intake of at least $500 \mathrm{IU}$ a day in addition to that supplied by the typical formula seems to be a reasonable regimen for infants weighing 2000-2500 $\mathrm{g}$ at birth. However, for infants weighing less than $2000 \mathrm{~g}$ at birth and of gestation below 38 weeks, administration of $1 \alpha-\mathrm{OHD}_{3}(0 \cdot 1 \mu \mathrm{g} / \mathrm{kg}$ a day or more) may be more effective for preventing rickets.

We thank the Chugai Pharmaceutical Company (Japan) for some of the $1 \alpha \mathrm{OHD}_{3}$ used in this study.

This study was supported in part by a Research Grant for the Intractable Diseases from the Ministry of Health and Welfare of Japan. 


\section{References}

1 Lewin P, Reid M, Reilly B J, Swyer P, Fraser D. Iatrogenic rickets in low-birth-weight infants. $J$ Pediatr 1971 ; 78: 207-10.

2 Arnaud S B, Stickler G B, Haworth J C. Serum 25 hydroxyvitamin D in infantile rickets. Pediatrics 1976; 57 : 221-5.

3 Hillman L S, Haddad J G. Human perinatal vitamin D metabolism 1: 25-hydroxyvitamin $D$ in maternal and cord blood. J Pediatr 1974; 84: 742-9.

4 Rosen J F, Roginsky M, Nathenson G, Finberg L. 25-hydroxyvitamin D plasma levels in mothers and their premature infants with neonatal hypocalcemia. Am J Dis Child 1974; 127: 220-3.

5 Hillman L S, Huebener D V, Haddad J G. Long term effects of low 25-hydroxyvitamin D (25-OHD) serum concentrations in premature infants. A preliminary report. In: Norman A W, Schaefer K, Herrath D V, et al., eds. Vitamin D Fourth Workshop: basic research and its clinical applications. Berlin: de Gruyter, 1979: 331-4.

- Wolf $\mathrm{H}$, Gràff V, Offermann $\mathrm{G}$. The vitamin $\mathrm{D}_{3}$ requirement for premature infants. In: Norman A W, Schaefer K, Herrath D V, et al., eds. Vitamin D Fourth Workshop: basic research and its clinical applications. Berlin: de Gruyter, 1979: 349-52.

7 Smith C A, Nelson N M, eds. The physiology of the newborn infant, fourth edition. Springfield: Thomas, 1976: 520-3.

${ }^{8}$ Seino $Y$, Shimotsuji T, Ishida M, Ishii T, Yabuuchi $H$. Rickets in infancy and childhood. Endocrinol Jpn 1979; 26: Supplement, 95-100.

- Hillman L S, Haddad J G. Perinatal vitamin D metabolism. J Pediatr 1975; 86: 928-35.
10 Caffey J. Pediatric $X$-ray diagnosis, sixth edition. Chicago: Year Book Medical Publishers, 1972: 1222-9.

11 Shimotsuji T, Seino Y, Yabuuchi H. A competitive protein binding assay for plasma 25 -hydroxyvitamin $D_{3}$ in normal children. Tohoku J Exp Med 1976; 118: 233-40.

12 Seino $Y$, Shimotsuji $T$, Yamaoka $M$, et al. Plasma 1,25-dihydroxyvitamin $D$ concentrations in cords, newborns, infants, and children. Calcif Tissue Int 1980; 30: $1-3$.

13 Fukushima M, Suzuki Y, Tohira Y, et al. Metabolism of $1 \alpha$-hydroxyvitamin $D_{3}$ to $1 \alpha, 25$-dihydroxyvitamin $D_{3}$ in perfused rat liver. Biochem Biophys Res Commun 1975; 66: 632-8.

14 Balsan S, Garabedian M, Sorgniard R, Holick M F, DeLuca H F. 1,25-dihydroxyvitamin $D_{3}$ and $1, \alpha$-hydroxyvitamin $\mathrm{D}_{3}$ in children: biologic and therapeutic effects in nutritional rickets and different types of vitamin D resistance. Pediatr Res 1975; 9: 586-93.

15 Chan G M, Tsang R C, Chen I-W, DeLuca H F, Steichen $\mathrm{J} J$. The effect of $1,25(\mathrm{OH})_{2}$ vitamin $\mathrm{D}_{3}$ supplementation in premature infants. $J$ Pediatr 1978; 93: 91-6.

16 Reade T M, Scriver C R, Glorieux F H, et al. Response to crystalline $1 \alpha$-hydroxyvitamin $D_{3}$ in vitamin $D$ dependency. Pediatr Res 1975; 9: 593-9.

17 Lubchenco L O, Searls D T, Brazie J V. Neonatal mortality rate: relationship to birth weight and gestational age. J Pediatr 1972; 81 : 814-22.

Correspondence to Dr Y Seino, Department of Paediatrics, Osaka University Hospital, Fukushimaku, Osaka, Japan 553.

Received 28 May 1980 